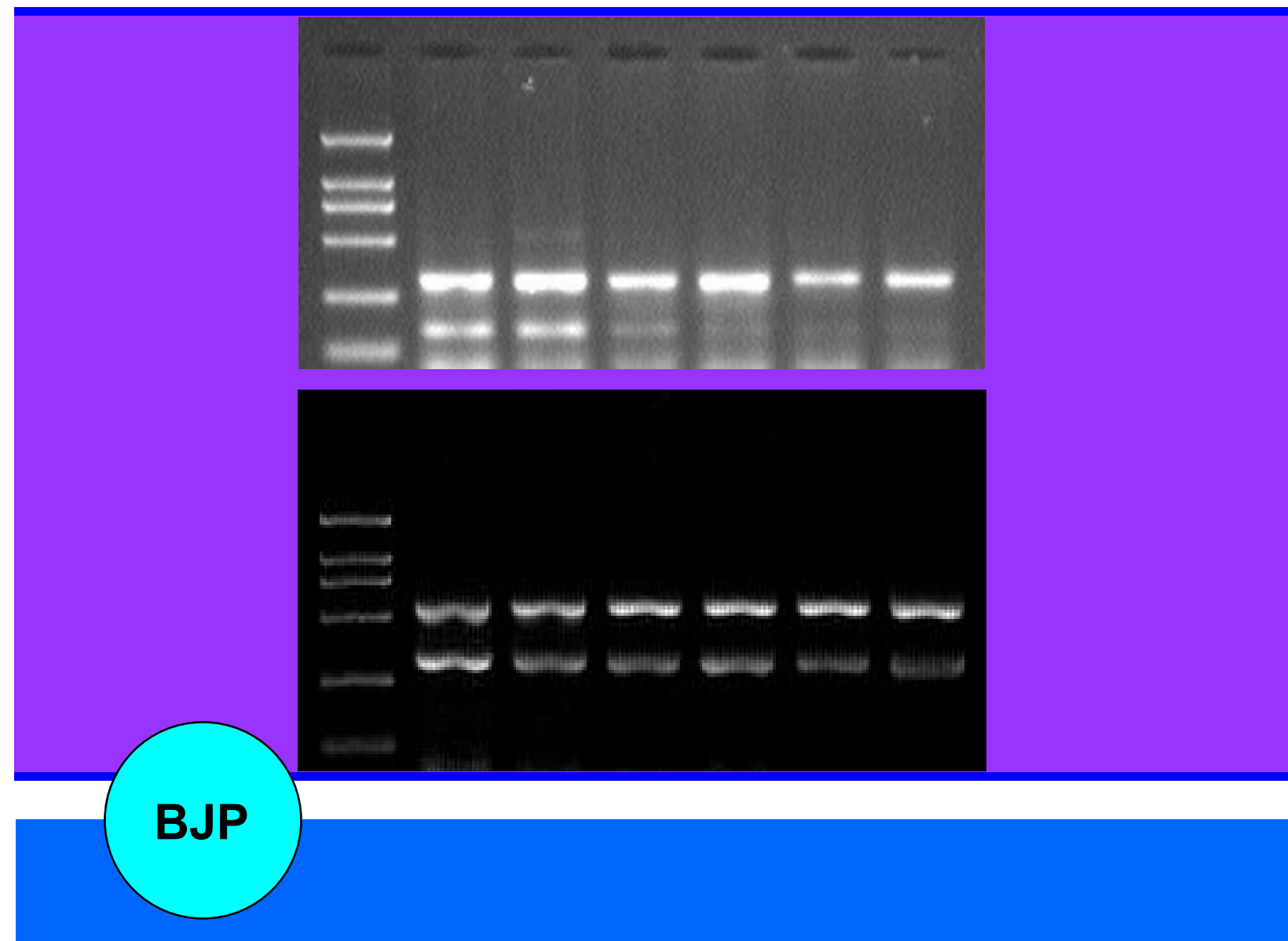

Bangladesh Journal of Pharmacology

Research Article

Inhibition of the expression of a proliferation-induced ligand APRIL in HepG2 cell line and the reversal on tumor immune evasion by Chinese medicine 


\title{
Inhibition of the expression of a proliferation-induced ligand APRIL in HepG2 cell line and the reversal on tumor immune evasion by Chinese medicine
}

\author{
Shi Hai Kan', Jing Tang², Du Jun Li², Zhi Qiang Wang', Chun Xia Li3 and Fei Huang1 \\ ${ }^{1}$ Department of Human Anatomy, Binzho u Medical University, 346 Guanhai Road, Yantai, 264003, China; \\ ${ }^{2}$ Department of Laboratory Medicine, Yantai Economic and Techno-logical Development Zone Hospital, 11 Taishan \\ Road, Yantai, 264006, China; ${ }^{3}$ Department of immunology, Jining Medical University, 16 Hehua Road, Jining, \\ 272067, China.
}

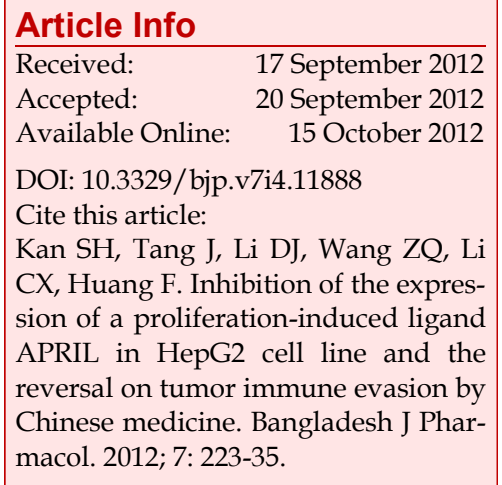

Article Info

Accepted:

Available Online: 15 October 2012

DOI: $10.3329 /$ bjp.v7i4.11888

Cite this article:

Kan SH, Tang J, Li DJ, Wang ZQ, Li APRIL in HepG2 cell line and the Chinese medicine. Bangladesh J Pharmacol. 2012; 7: 223-35.

\begin{abstract}
This study was designed to examine the role and mechanism of ICA, Baicali in combination with ADM on inhibiting the expression of APRIL in HepG2 cells. MTT assay was used to explore tumor cells proliferation and cytotoxic activity. RT-PCR was used to examine the expression level of APRIL, its receptor HSPG and apoptosis-associated gene bcl-2. ICA, Baicali and ADM can significantly inhibit the proliferation activity of HepG2 cells in a timedependent manner, and this inhibition of cell proliferation was time dependent; APRIL and its receptor HSPG were strongly expressed on HepG2 cells. In conclusion, by inhibiting the expression of bcl-2 on HepG2 cells, ICA, Baicali and ADM could significantly enhance the susceptibility of HepG2 cells to lysis by CD3AK, reverse tumor immune evasion.
\end{abstract}

\section{Introduction}

A proliferation-induced ligand APRIL is a member of TNF, normally it has expressed very weak, adjust lymphocyte proliferation and humoral immune response. But in recent years it was found high level expression in tumor cells and tumor tissue, and it has promoting tumor cells proliferation and inhibiting tumor cell apoptosis role (Hahne et al., 1998; Roth et al., 2001; Wang et al., 2011; Yu et al., 2000). So, to further study the mechanism of APRIL and to find the inhibitor of it can provide the new type agents and drugs for the treatment of the tumors with high expression of APRIL. Our team studying on the immune modification effects of the Chinese medicine monome, biological agents and chemotherapeutic drugs on tumor cells for many years, and obtained some achievements on inducing the tumor cells differentiation and apoptosis ( $\mathrm{Xu}$ et al., 2010). On this basis, the study applied the Chinese medicine monomer ICA, BAI combining chemotherapeutic drugs ADM to HepG2 cells, using some methods like MTT, RT-PCR to study the inhibiting expression of APRIL on HepG2 cells and the proliferation of tumor cells.

\section{Materials and Methods \\ Cell lines and main reagents}

The HepG2 cells was long-term preserved and passaged by our laboratory. Our team purify ICA and BAI which purity $>96 \%$. ADM is the products of Haizheng Pharmaceutical Co. Limited Company of Zhejiang. DMEM and Trypsin is the products of Gibco, and MTT is the products of Promega RhIL-2 is that the products of medical biotechnology Co. Ltd. of victory are fitted in Weihai, CD3McAb is the products of eBioscience 
Company. RT-PCR reagents are purchased from shanghai \& biological engineering and technical services Ltd. APRIL gene upstream primer 5'TCTGTCCTGCACCTGGTTCC-3', downstream primer 5'-CAGCAGATAA ACTCCAGCATCCT-3', augmentation gene fragment length $150 \mathrm{bp}$; HSPG gene upstream primer 5'-TAGGC ACGCTCAAGGGAC-3', downstream primer 5'-TCCTAGCTCCCTGCGAAGCA$3^{\prime}$, augmentation gene fragment length $225 \mathrm{bp}$; bcl-2 gene upstreamprimer5'-CGACGACTTCTCCCGCCG CTACCGC-3', downstreamprimer5'-CCGCATGCT GGGGCCGTACAGTTCC-3', augmentation gene fragment length 318 bp; $\beta$-actin upstream primer 5'G T G G G G C G C C C C A G G C A C C A - 3 ', downstreamprimer 5 '-CTCCT TAATGTCAC GCACGATTTC-3', augmentation gene fragment length 506 bp; $\beta$-actin upstream primer 5'ATCATGTTTGAGACCTTCAACA-3', down-stream primer 5'-CATCTCTTGCTCGAAGTCCA-3', augmentation gene fragment length $318 \mathrm{bp}$, synthesis from shanghai \& biological engineering and technical services Ltd.

Influence of ICA, BAI and ADM on HepG2 cells proliferation was tested by MTT methods (Nurwidya et al., 2012)

Logarithm period HepG2 cells, cell concentration is $5 \times$ $10^{4} / \mathrm{mL}$, were cultured in 96 hole plate, and then incubated overnight in $37^{\circ} \mathrm{C}, 5 \% \mathrm{CO}_{2}$ incubator. On second days, different concentrations of ICA, BAI and ADM was joined in cells of the experimental groups, drug effects on the final concentration respectively ICA 200, 100, 50, 25, 12.5, $6.3 \mu \mathrm{g} / \mathrm{mL}$; BAI 400, 200, 100, 50, 25, $12.5 \mu \mathrm{g} / \mathrm{mL}$; ADM 32, 16, 8, 4, 2, $1 \mu \mathrm{g} / \mathrm{mL}$, and $10 \%$ calf serum DMEM culture liquids was joined in cells of the control group, and then continue incubating for 48 hours, and joining on MTT $5 \mathrm{mg} / \mathrm{mL}$ ) four hours before the end of culture. After four hours test the D values on the enzyme mark instrument, the detection wavelength on $570 \mathrm{~nm}$, and the reference wavelength on $630 \mathrm{~nm}$, and then calculate the $\mathrm{D}$ values with $570 \mathrm{~nm}$ subtract $630 \mathrm{~nm}$.

\section{Influence of ICA, BAI and ADM on HepG2 cells kinetics of proliferation was tested by MTT methods}

Logarithm period HepG2 cells, cell concentration $5 \times$ $10^{4} / \mathrm{mL}$, were cultured in four 96 hole plates, and then incubated overnight in $37^{\circ} \mathrm{C}, 5 \% \mathrm{CO}_{2}$ incubator. On second days, different concentrations of ICA, BAI and $\mathrm{ADM}$ was joined in cells of the experimental groups, drug effects on the final concentration respectively 25 $\mu \mathrm{g} / \mathrm{mL}$ ICA, $200 \mu \mathrm{g} / \mathrm{mL}$ BAI, $2 \mu \mathrm{g} / \mathrm{mL}$ ADM, $12.5 \mu \mathrm{g} /$ $\mathrm{mL} \mathrm{ICA} \mathrm{+} 1 \mu \mathrm{g} / \mathrm{mL}$ ADM, $100 \mu \mathrm{g} / \mathrm{mL}$ BAI + $1 \mu \mathrm{g} / \mathrm{mL}$ $\mathrm{ADM}$, and the control group in accordance with methods described earlier, then cultured for different times for 24, 48, 72 and 96 hours.
RT-PCR methods was used to test the expression of APRILmRNA and its recipient HSPGmRNA on HepG2 cells (Kern et al., 2004; Sung et al., 2003)

Logarithm period HepG2 cells $\left(>1 \times 10^{6}\right)$, were extracted of total RNA, following the instructions of TRIZOL Reagent. Then conducting with RT-PCR after the quantitative. The PCR products of DNA by $\beta$-actin gene as reference, sweeping analysis by Gel Dos1000 gel analyzer.

RT-PCR methods was used to test the expression changes of APRILmRNA and bcl-2mRNA on HepG2 cells which disposed with ICA, BAI and ADM (Liang et al., 2011)

Collecting the HepG2 cells (each $>1 \times 10^{6}$ ) of the control group and the experimental groups which respectively effected by ICA $25 \mu \mathrm{g} / \mathrm{mL}$, BAI $200 \mu \mathrm{g} / \mathrm{mL}$, ADM 2 $\mu \mathrm{g} / \mathrm{mL}$, ICA $12.5 \mu \mathrm{g} / \mathrm{mL}+$ ADM $1 \mu \mathrm{g} / \mathrm{mL}$, BAI 100 $\mu \mathrm{g} / \mathrm{mL}+\mathrm{ADM} 1 \mu \mathrm{g} / \mathrm{mL}$ for 48 hours. Then conducting with RT-PCR and sweeping analysis by Gel Dos1000 gel analyzer.

MTT method was used to study the variation of CD3AK cells mediated cytotoxicity against HepG2 hepatoma cells which disposed with ICA, BAI and ADM (Sadiq and Mansour, 2011)

Routine preparation of human peripheral blood mononuclear cells, regulating cell density to $1 \times 10^{6} / \mathrm{mL}$ with containing $10 \%$ fetal calf serum 1640 medium, then joined in rhIL-2 $100 \mathrm{U} / \mathrm{mL}$ and CD3mAb $0.1 \mu \mathrm{g} / \mathrm{mL}$ inducting of CD3AK cells, and then incubated in $37^{\circ} \mathrm{C}$, $5 \% \mathrm{CO}_{2}$ incubator for five days. Collecting the HepG2 cells of each groups of methods 1.5 as target cells, with density of $1 \times 10^{5} / \mathrm{mL}$, were cultured in 96 hole plates with $100 \mu \mathrm{L} /$ hole. Taking the culture of 5D CD3AK as effector cells, with cell density of $2.5 \times 10^{6} / \mathrm{mL}, 1.25 \times$ $10^{6} / \mathrm{mL}, 0.625 \times 10^{6} / \mathrm{mL}, 0.3125 \times 10^{6} / \mathrm{mL}$, joined in each groups of target cells, in accordance with effector target ratio of $25: 1,12.5: 1,6.25: 1,3.125: 1$, and the different density of effector cells, untreated target cells control, blank control groups, and then incubated in $37^{\circ}$ C, $5 \% \mathrm{CO}_{2}$ incubator for 24 hours, and the testing methods described previously. Then calculating killing rate according to the following formula: Killing rate (\%) $=1$-[(experimental group-effector cells in control group) D/target cell group D] $\times 100 \%$.

RT-PCR method was used to study the expression changes of apoptosis related gene bcl-2mRNA on HepG2 cells after effected by CD3AK

Mixed the CD3AK with the each treatment group, control group HepG2 cells by 12.5:1 in accordance with methods 1.6 incubating for 24 hours, and then to abandon suspension CD3AK and collect of adherent cells $\left(>1 \times 10^{6}\right)$. Then conducting with RT-PCR and sweeping analysis by Gel Dos1000 gel analyzer. 


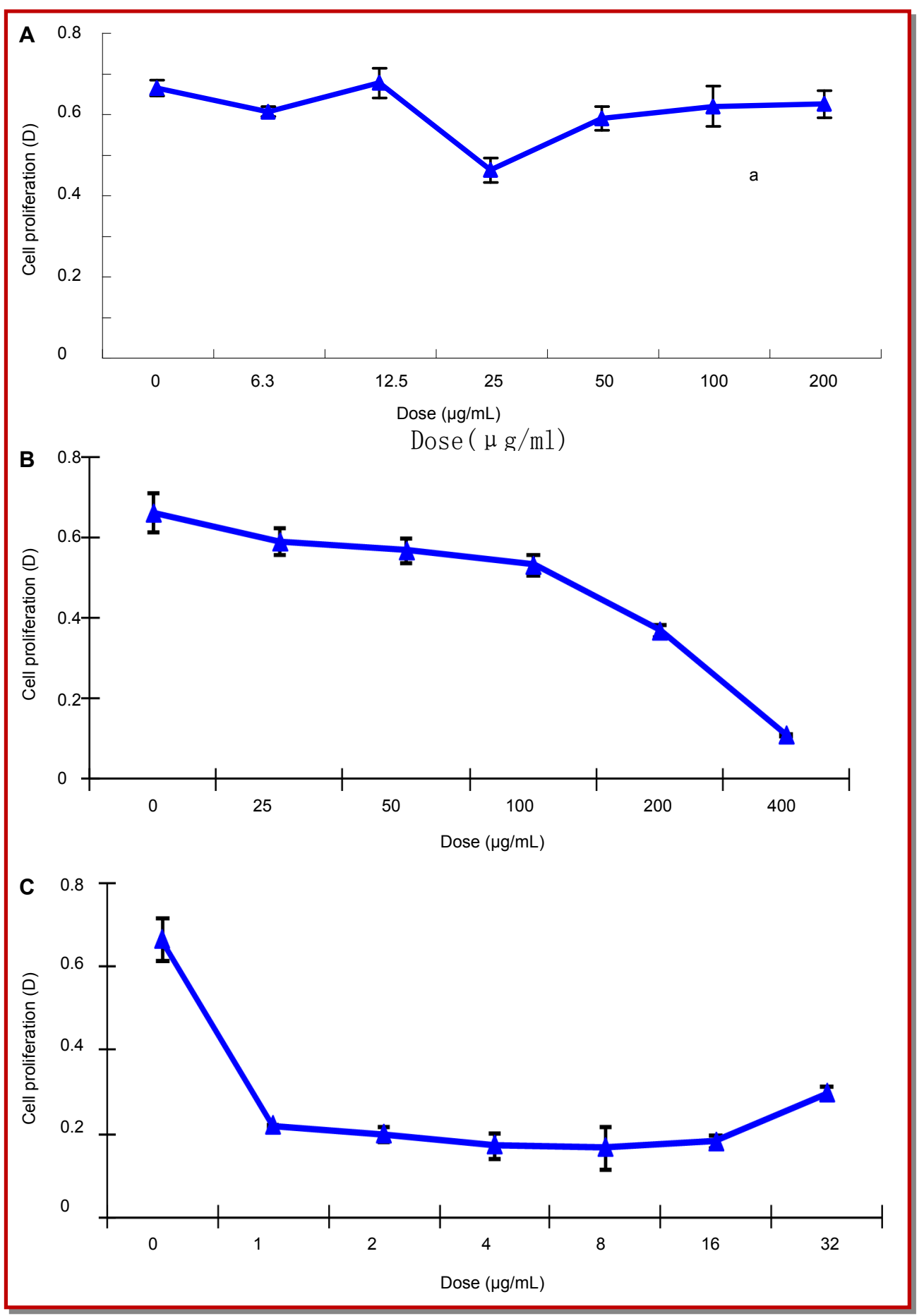

Figure 1: Influence of ICA (A), BAI (B), ADM (C) on HepG2 cells proliferation a $p<0.01$ vs control , n $=3$

\section{Statistical processing}

SPSS12 software package was used to perform t-test and $\chi^{2}$ test.

\section{Results}

As shown in Figure 1, HepG2 cells proliferation were inhibited after effected by ICA (A), BAI (B) combing ith ADMC for 48 hours, of which ICA $25 \mu \mathrm{g} / \mathrm{mL}, \mathrm{BAI} 400$, 200, $100 \mu \mathrm{g} / \mathrm{mL}, \mathrm{ADM} 16,8,4,2 \mu \mathrm{g} / \mathrm{mL}$ experimental groups inhibition of proliferation effect is obvious compared with untreated control group.

As shown in Figure 2, of each experimental groups, HepG2 cells inhibition of proliferation effect is obvious compared with untreated control group, and the 


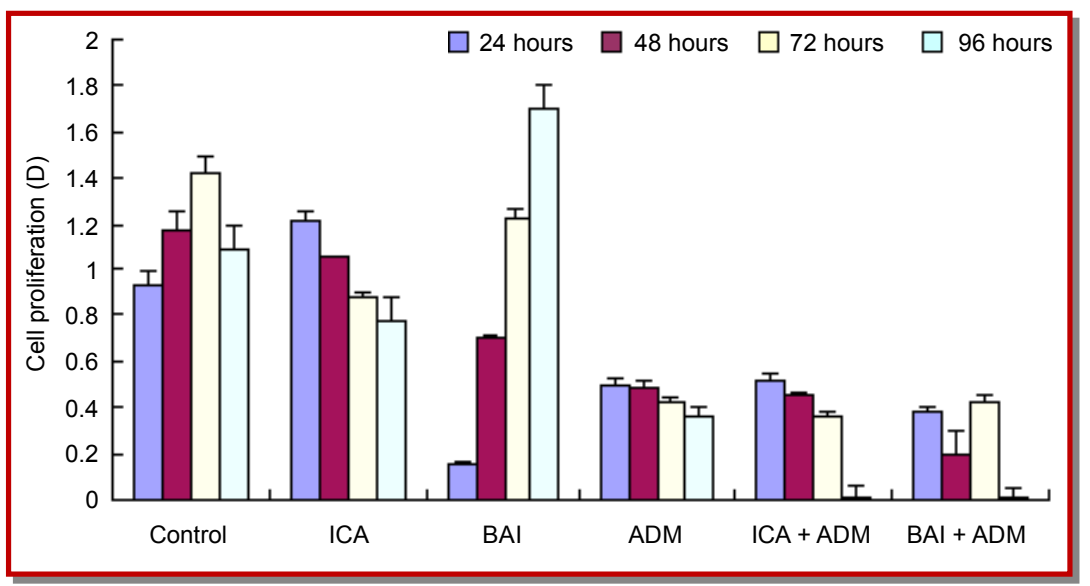

Figure 2: Influence of different time of ICA, BAI, ADM on HepG2 cells proliferation; $n=3$

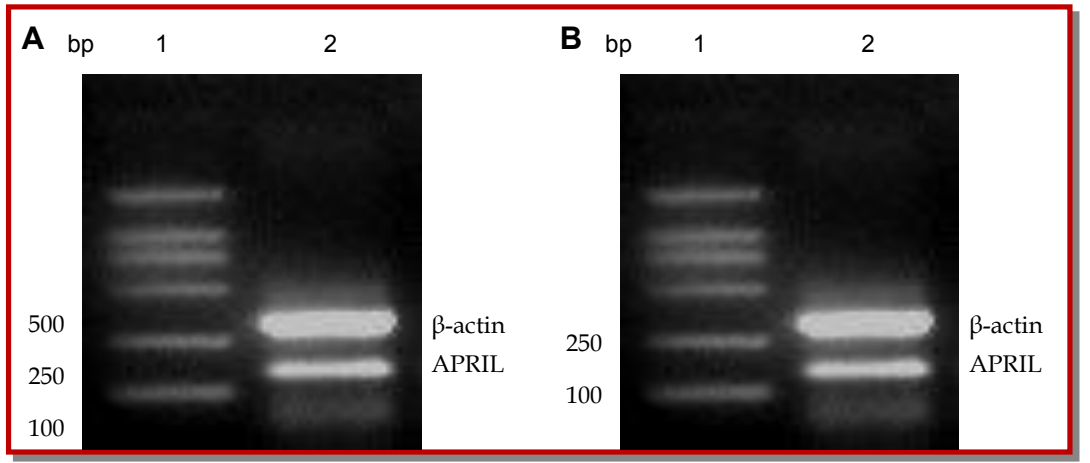

Figure 3: Expression of APRILmRNA A), HSPGmRNA (B) on HepG2 cells detected of RT-PCR. 1. Marker DL2000; 2. APRILmRNA; 3. HSPGmRNA

coding gene is located on chromosome 17p13.1 (Rennert et al., 2000). Expression of APRIL in normal tissue, the function related to regulation of lymphocyte proliferation and humoral immune response. Study finds (Novak et al., 2004; Okano et al., 2005), APRIL in a variety of tumor cells (such as colon cancer, liver cancer, glioma, multiple myeloma) have high expression, and ectopic expression of APRIL in autocrine, paracrine or endocrine form corresponding receptors BCMA, TACI or HSPG binding, promote the proliferation of tumor cells (Jang et al., 2011; MhawechFauceglia et al., 2006). This study using the hepatoma cell line HepG2 as the object which has high expression of APRIL, observed that the high expression of APRILmRNA and its recipient HSPGmRNA on HepG2 cells, showing that the APRIL may in autocrine pass to the corresponding receptor HSPG promoting the proliferation of tumor cells in HepG2 cells. ICA, BAI and ADM acting on HepG2 cells for 48 hours with obvious cell proliferation inhibition, and the inhibition of proliferation effect were time dependent of ICA, $\mathrm{ADM}, \mathrm{ICA}+\mathrm{ADM}, \mathrm{BAI}+\mathrm{ADM}$ groups, the highest inhibition rate on 96 hours, respectively $(29.3 \pm 6.6)$, $(63.6 \pm 1.4),(99.0 \pm 0.1)$ and $(98.9 \pm 0.2) \%(p<0.05)$. ICA, $\mathrm{BAI}$ and ADM can inhibit the HepG2 cells proliferation, and at the same time, reduce the level of APRILmRNA expression in HepG2 cells, so showing that a possible mechanism of ICA, BAI and ADM inhibiting the tumor cells proliferation was cutting the APRILmRNA expression.

Some study found (Haiat et al., 2006; Tecchio et al., 2011), on non-Hodgkin lymphoma (NHL), APRIL can resistance to apoptosis of tumor cells through its receptor BCMA, TACI and HSPG, activating NF-kB, up -regulating the expression of bcl-2mRNA. This study found that bcl-2mRNA expression was decreased significantly on HepG2 cells treated by ICA, BAI and $\mathrm{ADM}$, and the relatively quantitative values from the control group of 1.0 fall to $0.8,0.8,0.8,0.7,0.7$. Showing that ICA, BAI and ADM can reduces the expression of Bcl-2mRNA by decreasing the expression of APRILmRNA, so as to inhibit tumor cell proliferation and resistance to apoptosis.

CD3AK is the heterogeneity of T killer cell populations activated by anti-CD3 monoclonal antibody and IL-2, with strong proliferation ability and efficient cytotoxic activity. Many researches (Chen et al., 2001; Zhang et al., 2003) show that CD3AK has cell cytotoxic and antitumor may through to the target, similar to the CTL directly killing. But in the tumor microenvironment, tumor cells can escape from CTL specific killing effect 


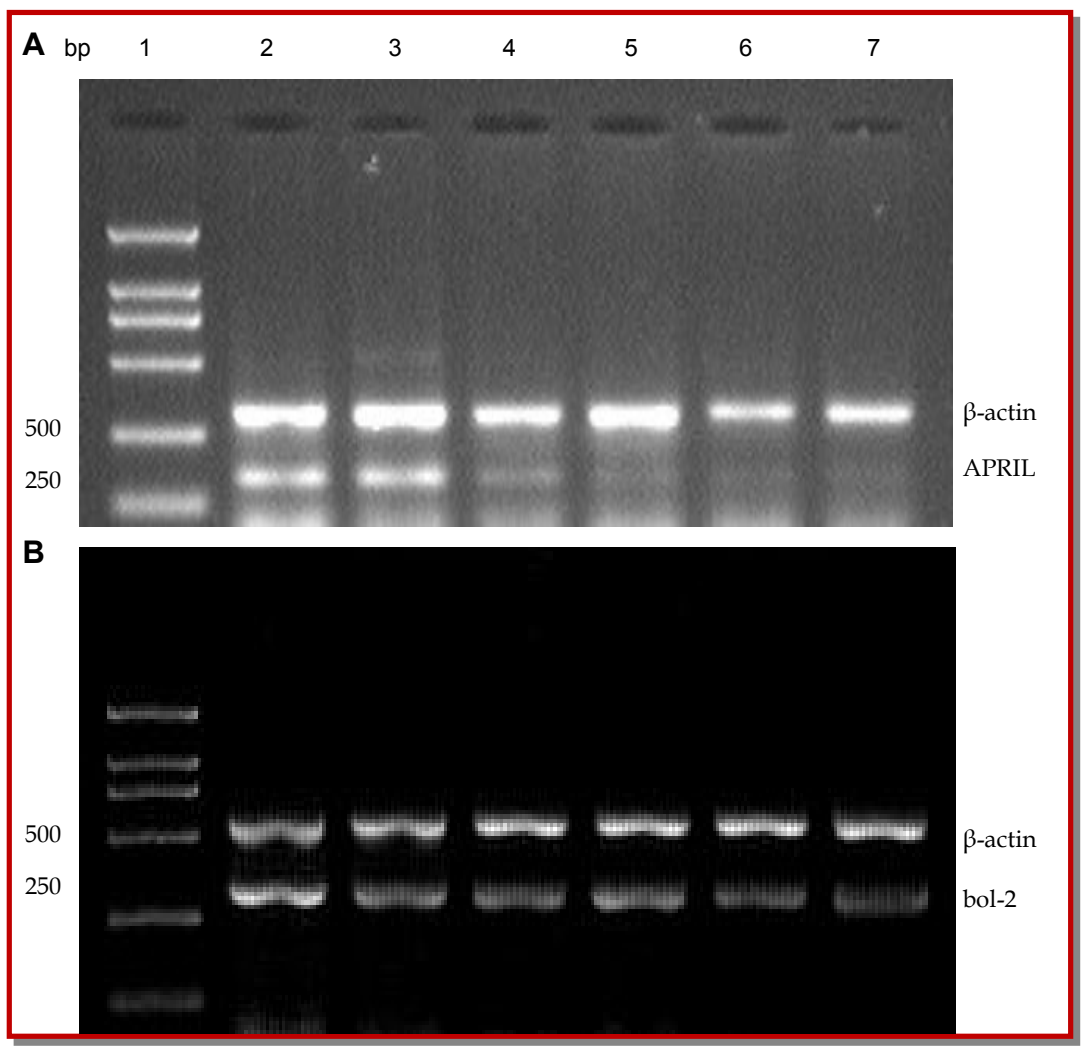

Figure 4: Expression of APRILmRNA (A), bcl-2Mrna (B) on HepG2 cells after treatment in different groups. 1: Marker DL2000; 2: Control; 3: ICA group; 4: BAI group; 5: ADM group; 6: ICA+ADM group; 7: BAI + ADM group

inhibition of proliferation effect were time dependent of ICA, ADM, ICA + ADM, BAI + ADM groups, the highest inhibition rate on 96 hours, respectively $(29.3 \pm$ $6.6),(63.6 \pm 1.4),(99.0 \pm 0.1)$ and $(98.9 \pm 0.2) \%(p<0.05)$.

As shown in Figure 3A, 318 bp $\beta$-actin and 149 bp APRIL gene fragment were clearly visible in Lane 2, high level expression of APRIL in HepG2 cells.

As shown in Figure 3B, 318 bp $\beta$-actin and 225 bp HSPG gene fragment were clearly visible in Lane 2, high level expression of the APRIL receptor HSPG in HepG2 cells. So these results indicates that the APRIL may pass to the corresponding receptor HSPG promoting the proliferation of tumor cells.

As shown in Figure 4A, 318 bp $\beta$-actin and 149 bp APRIL gene fragment were clearly visible in Lane 2, 3, $4,5,6,7$, the decreased expression of APRILmRNA on experimental groups of ICA, BAI, ADM, ICA + ADM and $\mathrm{BAI}+\mathrm{ADM}$ compared with the control group, strip becomes shallow gradually, and the relatively quantitative values from the control group of 0.7 fall to 0.7 , $0.7,0.5 .0 .4,0.4$.

As shown in Figure 4B, 506 bp $\beta$-actin and 318 bp bcl-2 gene fragment were clearly visible in Lane 2, 3, 4, 5, 6, 7, the decreased expression of bcl-2mRNA on experimental groups of ICA, BAI, ADM, ICA + ADM and BAI + ADM compared with the control group, strip becomes shallow gradually, and the relatively quantitative values from the control group of 1.0 fall to $0.8,0.8,0.8$, $0.7,0.7$.

As shown in Figure 5, with effector target ratio of 12.5:1, after 24 hours of interactions of effect or cell and target cell, the killing rate of CD3AK to HepG2 cells on experimental groups of ICA, BAI, ADM, ICA + ADM and BAI + ADM was respectively (97.2 \pm 5.1$),(93.1 \pm 9.9),(60.5 \pm$ $5.7),(43.9 \pm 8.2),(47.3 \pm 2.7) \%$, which is obviously higher than the control group $(30.0 \pm 4.5) \%(\mathrm{p}<0.01)$.

As shown in the Table I, after effected by CD3AK, the relatively expression quantitative of bcl-2mRNA on HepG2 cells from the control group of 0.9 fall to $0.7,0.7$, $0.5,0.7,0.6$ and is obviously lower than before CD3AK effects.

\section{Discussion}

Malignant tumor is a serious threat to human health, to search for effective drugs and treatment has been a hot and difficult problem to solve. Proliferation-induced ligand APRIL also known as TALL22 or TRDL-1, is a new member of the family of TNF ligand. In 1998, it first discovered and cloned by Hahne (Hahne et al., 1998). APRIL is composed of 250 amino acids with a type II transmembrane single-chain glycoprotein, its 


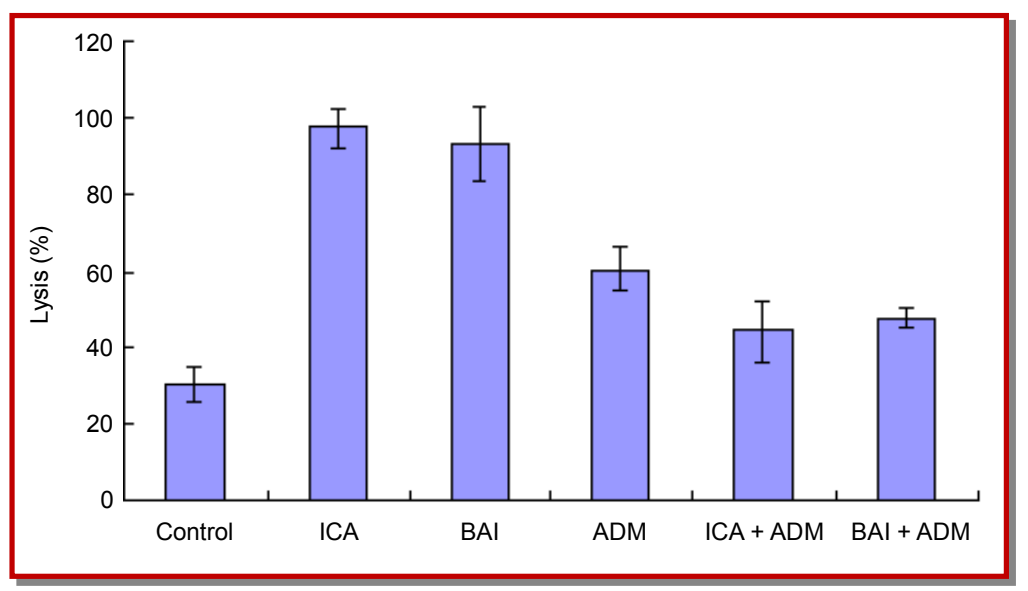

Figure 5: Effects of ICA, BAI, ADM on the sensitivity of HepG2 cells to CD3AK lysis; n=3

\section{Table I}

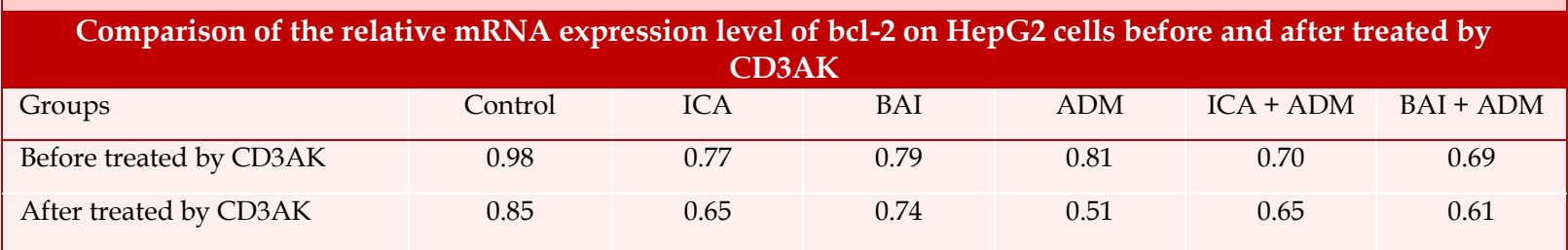

through multiple mechanisms. Tumor cells often high expression of multiple gene products such as the Bcl-2 families, these molecules can resist the activation of CTL mediated tumor cell apoptosis, in favor of tumor cell dysplasia (Andersen et al., 2005; Kumar and $\mathrm{Xi}$, 2011; Li et al., 2011; Maniwa et al., 2011).

This study found, with effector target ratio of 12.5:1, after 24 hours of interactions of effector cell and target cell, the killing rate of CD3AK to HepG2 cells on experimental groups of ICA, BAI, ADM, ICA + ADM and BAI + ADM was respectively (97.2 \pm 5.1$),(93.1 \pm$ $9.9),(60.5 \pm 5.7),(43.9 \pm 8.2),(47.3 \pm 2.7) \%$, which is obviously higher than control group $(30.0 \pm 4.5) \%$, showing that with the decrease of apoptosis resistance gene bcl-2mRNA expression level, enhanced HepG2 cell to CD3AK killer sensitivity on experimental groups. And after effected by CD3AK, the relatively expression quantitative of bcl-2mRNA on HepG2 cells is obviously lower than before CD3AK, the quantitative from 1.0 fall to 0.9 on control groups and from $0.8,0.8,0.8,0.7,0.7$ each fall to $0.7,0.7,0.5,0.7,0.6$ on experimental groups of ICA, BAI, ADM, ICA + ADM and BAI + ADM. Indicates that the $\mathrm{CD} 3 \mathrm{AK}$ killing mechanism related to the down-regulation of target cells of Bcl-2 mRNA expression level. So, ICA, BAI and ADM can significantly reduce apoptosis resistance gene bcl-2 expression, enhances HepG2 cell for CD3AK killer sensitivity, reversion of tumor cells immune escape function.

Tumor chemical therapy can kill normal cells at the same time, causing serious adverse effects. This study will be ADM with small dose of Chinese herbal monomer, and can also achieve the same proliferation inhibition on HepG2 cells with high doses of ADM. Therefore, the results of this study for clinical chemotherapy combined with traditional Chinese medicine treatment, reduce the chemotherapy drug side effect method discuss, provide new experimental evidence.

\section{Contribution}

Shi Hai Kan and Jing Tang contributed equally in this study.

\section{Acknowledgements}

This research is supported by the Educational Commission of Shandong Province (No. J08LJ53) and the natural science foundation of Shandong Province Youth Fund Project (No. ZR2011CQ041).

\section{References}

Andersen MH, Svane IM, Kvistborg P, Nielsen OJ, Balslev E, Reker S, Becker JC, Straten PT. Immunogenicity of Bcl-2 in patients with cancer. Blood 2005; 105: 728-34.

Chen BA, Chen SN, Li CP, Xia S, Jin BC, Wang J, Shao ZY, Gao C, Ding JH, Sun YY. Effect of autologous or allogeneic antiCD3 monoclonal antibody activated killer cells on normal hematopoietic cells. Zhongguo shi yan xue ye xue za zhi 2001; 9: 338-42. 
Hahne M, Kataoka T, Schroter M, Hofmann K, Irmler M, Bodmer JL, Schneider P, Bornand T, Holler N, French LE, Sordat B, Rimoldi D, Tschopp J. APRIL, a new ligand of the tumor necrosis factor family, stimulates tumor cell growth. J Exp Med. 1998; 188: 1185-90.

Haiat S, Billard C, Quiney C, Ajchenbaum-Cymbalista F, Kolb JP. Role of BAFF and APRIL in human $\beta$-cell chronic lymphocytic leukaemia. Immunology 2006; 118: 281-92.

Jang YS, Kim JH, Seo GY, Kim PH. TGF-beta1 stimulates mouse macrophages to express APRIL through Smad and p38MAPK/CREB pathways. Mol Cell. 2011; 32: 251-55.

Kern C, Cornuel JF, Billard C, Tang R, Rouillard D, Stenou V, Defrance T, Ajchenbaum-Cymbalista F, Simonin PY, Feldblum S, Kolb JP. Involvement of BAFF and APRIL in the resistance to apoptosis of $\beta$-cell through an autocrine pathway. Blood 2004; 103: 679-88.

Kumar R, Xi Y. MicroRNA, epigenetic machinery and lung cancer. Thoracic Cancer. 2011; 2: 35-44.

Li X, Wainscott C, Xi Y. MicroRNA provides insight into understanding esophageal cancer. Thoracic Cancer. 2011; 2: $134-42$.

Liang Y, Fu D, Hu G. Metadherin: An emerging key regulator of the malignant progression of multiple cancers. Thoracic Cancer. 2011; 2: 143-48.

Maniwa Y, Nishio W, Yoshimura M. Application of hRad9 in lung cancer treatment as a molecular marker and a molecular target. Thoracic Cancer. 2011; 2: 7-15.

Mhawech-Fauceglia P, Kaya G, Sauter G, McKee T, Donze O, Schwaller J, Huard B. The source of APRIL up-regulation in human solid tumor lesions. J Leukoc Biol. 2006; 80: 697-704.

Novak AJ, Darce JR, Arendt BK, Harder B, Henderson K, Kindsvogel W, Gross JA, Greipp PR, Jelinek DF. Expression of BCMA, TACI, and BAFF-R in multiple myeloma: A mechanism for growth and survival. Blood 2004; 103: 68994.

Nurwidya F, Takahashi F, Takahashi K. Meeting report: Current cancer perspectives from the 9th Annual Meeting of the Japanese Society of Medical Oncology. Thoracic Cancer 2012; 3: 94-97.

Okano H, Shiraki K, Yamanaka Y, Inoue H, Kawakita T, Saitou Y, Yamaguchi Y, Enokimura N, Ito K, Yamamoto N, Sugimoto K, Murata K, Nakano T. Functional expression of a proliferation-related ligand in hepatocellular carcinoma and its implications for neovascularization. World J Gastro- enterol. 2005; 11: 4650-54.

Rennert P, Schneider P, Cachero TG, Thompson J, Trabach L, Hertig S, Holler N, Qian F, Mullen C, Strauch K, Browning JL, Ambrose C, Tschopp J. A soluble form of $\beta$-cell maturation antigen, a receptor for the tumor necrosis factor family member APRIL, inhibits tumor cell growth. J Exp Med. 2000; 192: 1677-84.

Roth W, Wagenknecht B, Klumpp A, Naumann U, Hahne M, Tschopp J, Weller M. APRIL, a new member of the tumor necrosis factor family, modulates death ligand-induced apoptosis. Cell death and differentiation, 2001; 8: 403-10.

Sadiq A, Mansour KA. Esophageal cancer: Recent advances. Thoracic Cancer. 2011; 2: 75-83.

Sung YK, Hwang SY, Farooq M, Kim JC, Kim MK. Growth promotion of HepG2 hepatoma cells by antisense-mediated knockdown of glypican-3 is independent of insulin-like growth factor 2 signaling. Exper Mol Med. 2003; 35: 257-62.

Tecchio C, Nichele I, Mosna F, Zampieri F, Leso A, Al-Khaffaf A, Veneri D, Andreini A, Pizzolo G and Ambrosetti AA proliferation-inducing ligand (APRIL) serum levels predict time to first treatment in patients affected by $\beta$-cell chronic lymphocytic leukemia. Eur J Haematol. 2011; 87: 228-34.

Wang F, Chen L, Ding W, Wang G, Wu Y, Wang J, Luo L, Cong H, Wang Y, Ju S, Shao J, Wang H. Serum APRIL, a potential tumor marker in pancreatic cancer. Clin Chem Laboratory Med. 2011; 49: 1715-19.

$\mathrm{Xu} \mathrm{Y,} \mathrm{Liu} \mathrm{H,} \mathrm{Chen} \mathrm{J,} \mathrm{Zhou} \mathrm{Q.} \mathrm{Comparisons} \mathrm{between} \mathrm{the}$ National Comprehensive Cancer Network (NCCN) nonsmall-cell lung cancer (NSCLC) Clinical Practice Guidelines (Chinese version), the NCCN original edition, and the European Society for Medical Oncology NSCLC Guidelines in 2009. Thoracic Cancer. 2010; 1: 83-86.

Yu G, Boone T, Delaney J, Hawkins N, Kelley M, Ramakrishnan M, McCabe S, Qiu WR, Kornuc M, Xia XZ, Guo J, Stolina M, Boyle WJ, Sarosi I, Hsu H, Senaldi G, Theill LE. APRIL and TALL-I and receptors BCMA and TACI: System for regulating humoral immunity. Nature Immunol. 2000; 1: 252-56.

Zhang JC, Wang ZR, Cheng YJ, Yang DZ, Shi JS, Liang AL, Liu NN, Wang XM. Expression of proliferating cell nuclear antigen and CD44 variant exon 6 in primary tumors and corresponding lymph node metastases of colorectal carcinoma with Dukes' stage C or D. World J Gastroenterol. 2003; 9: 1482-86. 